\title{
Kecemasan Sosial dan Ketergantungan Media Sosial pada Mahasiswa
}

\author{
Fatih Azka, Dendih Fredi Firdaus, Elisa Kurniadewi \\ UIN Sunan Gunung Djati Bandung Jl. A.H Nasution No. 105 Bandung \\ e-mail: fatihazka66@gmail.com
}

\begin{abstract}
This study aims to examine the effect of social anxiety on social media dependence in university students. This research used the quantitative approach with a predictive correlation method. The instruments were social anxiety scale (92 items) refers to aspects of social anxiety from La Greca and Lopez, and the scale of dependence on social media (30 items) refers to Griffiths. The participants were 342 students of UIN Sunan Gunung Djati Bandung selected by random sampling. The results show that social anxiety influence dependence on social media in university students. The influence of social anxiety variables to dependence on social media is about 7.2\%. Most of the participants have social anxiety and social media dependence in the medium category.
\end{abstract}

Keywords: social anxiety, dependence on social media, student

\begin{abstract}
Abstrak
Penelitian ini dilakukan untuk mendapatkan informasi mengenai pengaruh kecemasan sosial terhadap ketergantungan media sosial pada mahasiswa. Dengan menggunakan pendekatan kuantitatif dan metode korelasi prediktif. Instrumen berupa skala kecemasan sosial (92 item) yang mengacu kepada aspek kecemasan sosial dari La Greca dan Lopez, serta skala ketergantungan pada media sosial (30 item) mengacu kepada Griffiths. Subjek penelitian sebanyak 342 orang mahasiswa UIN Sunan Gunung Djati Bandung yang dipilih secara random sampling. Hasil penelitian menunjukkan adanya pengaruh kecemasan sosial terhadap ketergantungan media sosial pada mahasiswa, dengan pengaruh sebesar 7.2\%. Mayoritas mahasiswa UIN Sunan Gunung Djati Bandung mempunyai kecemasan sosial dan ketergantungan media sosial dalam kategori sedang.
\end{abstract}

Kata Kunci: kecemasan sosial, ketergantungan pada media sosial, mahasiswa

\section{Pendahuluan}

Perkembangan teknologi saat ini semakin pesat sehingga membuat manusia lebih mudah, efektif dan efisien dalam melaksanakan kegiatan pada keseharian mereka. Adapun teknologi yang memiliki perkembangan begitu pesat saat ini yaitu adanya teknologi komunikasi dari internet. Internet berdampak positif dan negatif terhadap kehidupan manusia. Selain itu, internet juga telah mengubah cara hidup manusia. Dampak positif dari internet yaitu dapat berbelanja dengan online, bisa berkomunikasi antar saudara, sahabat di belahan bumi manapun pada waktu yang diinginkan termasuk bisa berkomunikasi dengan orang yang belum pernah bertemu serta memperoleh informasi yang dibutuhkan. Selain dampak positif, internet juga berdampak negatif. Sebagaimana hasil penelitian Elia (2009) yang menemukan bahwa $20 \%$ pengguna internet dapat terlibat dalam satu atau lebih masalah pengabaian diri, menghindari orang lain, terisolasi secara sosial, depresi, menurunnya produktivitas kerja akibat banyak bersosial media, munculnya masalah dalam relasi pernikahan, kecanduan seks, judi online, kegagalan studi karena tidak bisa mengatur penggunaan internet termasuk juga perilaku mengecek dan mengklik secara terus-menerus.

Kemudahan yang diberikan oleh media sosial membuat penggunanya menjadi cemas dan ketergantungan. Ketergantungan menurut definisi dari Dependence Theory yaitu bahwa ketergantungan memiliki kaitan dengan usaha pemenuhan 
kebutuhan atau pencapaian dari suatu tujuan yang bergantung pada sumber daya lain, dalam hal ini media sosial (Schrock, 2006). Media sosial dipercaya sebagai satu-satunya cara dalam memperoleh keinginan, seolah-olah individu tidak berdaya saat hidupnya tidak dilengkapi media sosial.

Kandell (1998) menyatakan bahwa salah satu pengguna media sosial yaitu mahasiswa. Mahasiswa menjadi lebih rentan terhadap ketergantungan pada media sosial. Berdasarkan survei yang disampaikan oleh APJII, pengguna media sosial yang memiliki intensitas tinggi adalah individu dengan tingkat pendidikan tinggi, artinya semakin tinggi tingkat pendidikan individu maka semakin tinggi juga intensitas kegiatan mereka dalam mengakses dan menggunakan media sosial (APJII, 2015). Kesibukan dan aktivitas mahasiswa biasanya membuat mereka menjadi ketergantungan pada internet dan media sosial.

Alasan mahasiswa memiliki kerentanan yang tinggi terhadap ketergantungan media sosial dibandingkan dengan kelompok masyarakat yang lain adalah karena mahasiswa berada pada fase emerging adulthood. Pada fase ini mahasiswa berada pada masa transisi dari remaja akhir menuju kepada dewasa awal dan sedang mengalami dinamika psikologis (Kandell, 1998). Mahasiswa juga sedang mengalami pencarian identitas prestasinya yang ditandai dengan proses pembentukan identitas diri dan berusaha untuk hidup secara mandiri dengan melepaskan diri dari pengaruh dan dominasi peran orang tua. Pada usia ini, mahasiswa memiliki kecenderungan untuk mencari makna hidup serta menjalin hubungan interpersonal yang lebih dekat dan terikat secara afektif. Fase emerging adulthood juga ditandai dengan karakter yang kurang stabil seperti untuk mengelola kebutuhan hidup, hubungan interpersonal, berkembangnya aspek dalam ranah afektif dan ranah kognitif. Ketika mahasiswa mendapatkan kesulitan dalam proses perkembangannya, maka untuk menyelesaikan masalah tersebut yaitu dengan aktivitas pemakaian media sosial yang lebih intensif, lebih penting dibanding dengan apa yang dilakukan oleh orang lain pada umumnya, karena menurut kelompok mahasiswa ini kegiatan online bisa membantu mereka dalam melebarkan serta memerkuat jejaring sosialnya (Smahel, Brown, \& Blinka, 2012).

Dari fenomena dan fakta di atas, peneliti tertarik untuk meneliti mahasiswa di Kota Bandung khususnya mahasiswa di UIN Sunan Gunung Djati Bandung. Tempat ini menjadi pilihan peneliti karena Kota Bandung termasuk dalam 5 daerah dengan aktivitas online paling tinggi di Indonesia. Pengguna media sosial meningkat pada setiap tahunnya. Data statistik menunjukkan bahwa tahun 2015 terdapat $22 \%$, kemudian pada tahun berikutnya bahkan mengalami peningkatan sebesar 43\% (Yahoo!-TNS, 2016).

Berdasarkan hasil observasi dan interview terhadap 30 orang mahasiswa UIN Sunan Gunung Djati Bandung yang dilakukan pada bulan April sampai dengan Juni 2017, ditemukan banyak mahasiswa yang memiliki ketergantungan terhadap media sosial. Mahasiswa tidak dapat menghentikan akses terhadap semua media sosialnya selama satu hari penuh. Mahasiswa cenderung menggunakan media sosial yang bertujuan untuk mengatasi hubungan yang kurang baik seperti harga diri yang rendah, hilangnya dukungan sosial di kehidupan nyata, kurangnya rasa kepercayaan diri, dan kekurangan fisik lainnya.

Fenomena awal yang ditemukan dalam penelitian ini menunjukkan bahwa dalam satu hari mahasiswa dapat mengakses media sosial dari smartphone mereka lebih dari 3 jam, dan waktu yang digunakan untuk mengakses media sosial dalam sehari yaitu sekitar 5 jam. Aktivitas yang paling sering dilakukan oleh mahasiswa di dunia maya adalah mengakses media sosial $(84.2 \%)$, melakukan pencarian/searching di google (65.7\%), bermain 
game online (39.2\%), menonton video $(38.9 \%)$, membaca berita (31.4\%), dan mengakses e-mail (30.7\%). Mahasiswa dapat menghabiskan sebanyak 35 jam dalam seminggu untuk mengakses media sosialnya dan hanya menghabiskan ratarata sekitar 3 jam waktunya dalam seminggu untuk belajar secara maksimal. Hal ini sungguh ironis bahwa mahasiswa lebih memerioritaskan untuk mengakses media sosial dibandingkan belajar. Bahkan ada juga beberapa mahasiswa yang menghabiskan waktu sampai 10 jam sehari dalam bermain ponselnya, dimana ratarata sekitar 184.6 menit sehari mereka gunakan untuk chatting dengan teman.

Hal ini sesuai fakta yang ditemukan di lapangan bahwa apabila dalam sehari mahasiswa tidak mendapat notifikasi di ponselnya, maka akan muncul perasaan resah yang diakibatkan oleh reaksi dari ketergantungan media sosial. Sebanyak 39\% mahasiswa mengalami ketakutan atau kecemasan sosial yang berlebihan dalam melewatkan moment-moment tertentu yang terjadi dalam kehidupan mereka. Sebanyak 32\% mahasiswa menyampaikan bahwa mereka mengalami perasaan takut saat tidak dapat mencapai tujuan mereka ketika melihat foto teman atau orang lain yang dengan mudahnya mengekspos kesuksesannya di media sosial. Mahasiswa dengan ketergantungan kepada media sosial menggunakan media sosialnya secara berlebihan akan mengalami kesulitan mengontrol penggunaan media sosialnya, dan bisa mengalami gangguan psikologis.

\section{Kecemasan Sosial}

Kecemasan sosial memiliki kaitan dengan kecemasan secara komunikatif. Hal ini digambarkan seperti perasaan takut atau khawatir saat individu berada pada situasi sosial. Individu yang mengalami kecemasan sosial akan mengembangkan perasaan-perasaan negatif dan memrediksi hal-hal negatif saat berinteraksi dan komunikasi dengan orang lain (DeVito, 2001). Individu tersebut memiliki kepri- badian dengan ciri-ciri seperti gugup, pemalu, pendiam, dan mengantisipasi untuk tidak berinteraksi dengan orang lain demi menghindari pandangan negatif dari orang lain terhadap dirinya (Geçer \& Gümüş, 2010).

Hasil penelitian yang dilakukan oleh Prayoga dan Akmal (2014) menyatakan adanya keterkaitan antara kecemasan sosial dan ketergantungan media sosial, individu yang memiliki kecemasan sosial akan menggunakan media sosial secara berlebihan untuk mengatasi hambatan yang ada pada dirinya. Hasil penelitian tersebut (Prayoga \& Akmal, 2014) menunjukkan adanya dampak negatif ketergantungan media sosial terhadap kehidupan sosial individu tersebut dalam hal fungsi interpersonalnya. Penelitian lain yang menyatakan bahwa terdapat hubungan antara kecemasan sosial dengan ketergantungan media sosial, yaitu penelitian yang dilakukan oleh Soliha (2015) yang menyatakan bahwa kecemasan sosial, depresi, dan rasa kesepian secara signifikan berpengaruh terhadap timbulnya ketergantungan pada media sosial.

Pada mahasiswa yang menjadi subjek dalam penelitian ini ditemukan bahwa mereka yang mengalami kecemasan sosial secara lisan merasa sangat cemas jika berkomunikasi dan bertatap muka secara langsung, yang akibatnya adalah mereka bergantung kepada media komunikasi yang dapat dilakukan secara tulisan dalam hal ini yaitu media sosial. Hal ini mengindikasikan bahwa dengan melalui komunikasi secara online membuat individu tersebut merasa didengarkan, mereka juga merasa lebih mudah dalam mengekspresikan dirinya. Situasi ini juga yang membuat penggunaan media sosial mengalami peningkatan secara pesat dan signifikan belakangan ini.

Mahasiswa dengan kecemasan sosial cenderung melakukan komunikasi secara online dengan memresentasikan dan mencitrakan dirinya sebaik mungkin agar mendapatkan kesan dan citra yang positif dari pihak lain, bahkan terkadang kesan 
yang ditampilkan tidak sesuai dengan diri aslinya. Kondisi ini membuat mahasiswa yang memiliki kecemasan sosial semakin mengalami ketergantungan media sosial.

\section{Ketergantungan Media Sosial}

Menurut penelitian yang dilakukan oleh Young (2011), bahwa individu dengan ketergantungan media sosial adalah individu yang memiliki kecenderungan yang kuat dalam melakukan aktivitas-aktivitas pada media sosial dan membatasi aktivitas sosialnya dalam dunia nyata. Ketergantungan media sosial dapat terlihat dari intensitas waktu yang digunakan oleh seseorang untuk terus terpaku pada media sosialnya yang berada pada smartphone atau segala macam alat elektronik yang memiliki akses terhadap media sosial. Akibatnya adalah banyak waktu yang digunakan untuk mengakses media sosial membuat individu tidak peduli dengan kehidupan di dunia nyatanya (Young, 2011).

Dalam penelitian ini ditemukan bahwa mahasiswa yang menggunakan media sosial untuk tujuan coping dalam melakukan interaksi dengan lingkungan sekitarnya akan lebih cenderung mengungkapkan diri di media sosial, tetapi di kehidupan sehari-hari individu tersebut memiliki rasa takut untuk mengungkapkan diri atau mempunyai pengungkapan diri yang rendah. Hal ini sesuai dengan pernyataan Niekamp (2010) bahwa media sosial memberikan kenyamanan tersendiri yang menyebabkan ketergantungan karena medianya yang anonim, tidak bertatap muka secara langsung, dan tidak adanya hambatan untuk berinteraksi dengan orang lain.

Terdapat dua alasan mengapa seseorang menjadi ketergantungan kepada media sosial. Pertama, menurut Prayoga dan Akmal (2014) bahwa media sosial dapat digunakan untuk mendukung interaksi sosial bagi individu yang kurang memiliki keterampilan sosial di dunia nyata sehingga media sosial digunakan untuk kompensasi sosialnya. Kedua, karena keterampilan bersosialisasi di media sosial dapat dimanfaatkan untuk dukungan sosial. Mahasiswa yang memiliki ketergantungan pada media sosial disebabkan oleh kecemasan sosial yang dimiliki oleh individu tersebut. Menurut salah satu mahasiswa yang diwawancarai menyatakan bahwa, "saya menggunakan media sosial berfungsi sebagai cara untuk mengobati kesendirian dan sebagai pengganti hubungan tatap muka yang tidak diperolehnya dalam kehidupan sehari-hari karena takut untuk melakukan kontak langsung dengan orang lain dan lebih memilih hanya komunikasi online"(A.N., 2017).

Mahasiswa dengan ketergantungan pada media sosial selain kurang memiliki kontrol dalam penggunaan media sosialnya, berakibat juga pada berkurangnya interaksi langsung secara tatap muka, selain karena disebabkan oleh kurangnya interaksi secara langsung terdapat sebab lain yang memengaruhi ketergantungan media sosial, yaitu kesulitan waktu mahasiswa untuk berinteraksi dan beradaptasi dengan lingkungan.

Berdasarkan fenomena yang ada di lapangan dan beberapa penelitian lain yang terkait dengan ketergantungan pada media sosial maka peneliti tertarik untuk melakukan penelitian lebih mendalam yang bertujuan untuk mengetahui apakah terdapat pengaruh kecemasan sosial terhadap ketergantungan media sosial pada mahasiswa.

\section{Metode Penelitian}

Penelitian ini menggunakan penelitian kuantitatif dengan metode korelasi prediktif. Adapun variabel yang akan diteliti adalah kecemasan sosial sebagai variabel prediktor dan ketergantungan media sosial sebagai variabel kriterion. Untuk melihat pengaruh variabel prediktor yaitu kecemasan sosial terhadap variabel kriterion yaitu ketergantungan media sosial, dengan menggunakan teknik analisis regresi sederhana. 
Populasi adalah mahasiswa UIN Sunan Gunung Djati Bandung yang menggunakan media sosial. Diperoleh data dari Kepala Bagian Akademik UIN Sunan Gunung Djati bahwa total mahasiswa aktif tahun akademik 2017/2018 adalah 23,257 mahasiswa. Sampel sebanyak 342 orang mahasiswa aktif tiap Fakultas di UIN Sunan Gunung Djati Bandung yang diperoleh melalui teknik random sampling Jumlah sampel tersebut diambil dari jumlah populasi yang lebih dari 20.000 menurut tabel Isaac dan Michael dengan tingkat kesalahan 5\% (Sugiyono, 2014).

Variabel kecemasan sosial diukur dengan skala kecemasan sosial berdasarkan teori Greca dan Lopez (1998). Skala kecemasan sosial yang digunakan terdiri dari beberapa aspek yaitu ketakutan akan evaluasi negatif, penghindaran sosial dan rasa tertekan yang dialami dalam situasi baru, serta penghindaran sosial dan rasa tertekan terhadap orang yang baru dikenal.

Dalam mengukur ketergantungan pada media sosial, peneliti mengadaptasi kuesioner tentang ketergantungan media sosial, yaitu alat ukur skala ketergantungan internet dari teori internet addiction (Griffiths, 2013) yang dikembangkan oleh Lemmens, Valkenburg, dan Peter (2009) yaitu menghabiskan banyak waktu untuk berpikir dan merencanakan apa yang akan dilakukan di media sosial, merasa sangat ingin dan terdesak untuk menggunakan media sosial, menggunakan media sosial untuk melupakan masalah pribadi, pernah mencoba untuk mengurangi penggunaan media sosial tetapi gagal, gelisah dan terganggu ketika dilarang menggunakan media sosial, terlalu sering menggunakan media sosial sehingga mengganggu aktivitas sehari-hari.

Dengan menggunakan formula koefisien korelasi pearson product moment diperoleh hasil perhitungan analisis item variabel kecemasan sosial yaitu item terpakai 70 item dan item tidak terpakai 22 item. Variabel ketergantungan pada media sosial yaitu item terpakai 24 item dan 6 item tidak terpakai.
Uji validitas menggunakan construct validity, dengan teknik korelasi pearson product moment. Hasil uji validitas dari kedua variabel yaitu rata-rata berada pada level validitas tinggi.

Uji reliabilitas menggunakan rumus Alpha Cronbach. Diperoleh koefisien alpha untuk skala kecemasan sosial sebesar .93 (reliabilitas sangat tinggi). Sedangkan skala ketergantungan pada media sosial mempunyai koefisien alpha sebesar .84 (reliabilitas tinggi). Dengan demikian dapat disimpulkan bahwa kedua skala mempunyai tingkat reliabilitas tinggi dan sangat tinggi sehingga dapat menunjukkan perbedaan antar responden dengan baik. Teknik analisis data menggunakan analisis regresi linier sederhana, untuk mencari hubungan kausalitas antara kecemasan sosial dengan ketergantungan media sosial.

\section{Hasil Penelitian dan Pembahasan}

\section{Hasil Penelitian \\ Uji asumsi klasik.}

Tabel 1

Hasil Perhitungan Uji Normalitas

\begin{tabular}{lcc}
\hline & & $\begin{array}{c}\text { Unstandardized } \\
\text { Residual }\end{array}$ \\
\hline $\mathrm{N}$ & Mean & 342 \\
$\begin{array}{l}\text { Normal } \\
\text { Parameters }\end{array}$ & $0 \mathrm{E}-7$ \\
& $\begin{array}{l}\text { Std. } \\
\text { Deviation }\end{array}$ & 8.98216678 \\
& Absolute & .057 \\
$\begin{array}{l}\text { Most Extreme } \\
\text { Differences }\end{array}$ & $\begin{array}{l}\text { Positive } \\
\text { Negative }\end{array}$ & .050 \\
& -.057 \\
Kolmogorov-Smirnov Z & 1.062 \\
Asymp. Sig. (2-tailed) & .209
\end{tabular}

Bagian utama dalam penelitian ini adalah membahas apakah variabel kecemasan sosial memengaruhi ketergantungan media sosial pada mahasiswa UIN Sunan Gunung Djati Bandung. Pengujian hipotesis menggunakan teknik analisis regresi linier sederhana. Sebelum analisis regresi tersebut dilakukan, maka perlu dilakukan uji asumsi klasik terlebih dahulu. 
Hasil uji normalitas KolmogorovSmirnov pada tabel 1 menunjukkan hasil $.209>.05$ sehingga dapat disimpulkan bahwa distribusi data tersebut memenuhi asumsi normalitas. Selanjutnya hasil uji linearitas menunjukkan nilai $.000<.05$ sehingga dapat disimpulkan memenuhi syarat linearitas. Setelah dilakukan uji heteroskedastisitas dengan pemilihan uji glejser, diketahui bahwa nilai p-value untuk variabel kecemasan sosial sebesar .73. Karena nilai $p$-value menunjukkan hasil lebih dari .05 maka dapat disimpulkan bahwa pada variabel prediktor tidak terdapat adanya gejala heteroskedastisitas. Dengan demikian persyaratan-persyaratan untuk analisis regresi linear sederhana sudah terpenuhi.

Pengujian kelayakan model regresi. Berdasarkan hasil uji anova diperoleh tingkat signifikansi (p-value) lebih kecil dari pada $\alpha(.000<.05)$, maka penelitian ini layak untuk diuji menggunakan model regresi karena variabel kecemasan sosial memiliki indikasi dapat memengaruhi variabel ketergantungan pada media sosial dalam penelitian ini.

\section{Koefisien determinasi.}

Tabel 2

Hasil Uji Koefisien Determinasi

\begin{tabular}{ccccc}
\hline Model & $\mathrm{R}$ & $\begin{array}{c}\mathrm{R} \\
\text { Square }\end{array}$ & $\begin{array}{c}\text { Adjusted } \\
\mathrm{R} \text { Square }\end{array}$ & $\begin{array}{c}\text { Std. Error of the } \\
\text { Estimate }\end{array}$ \\
\hline 1 & $.268^{\mathrm{a}}$ & .072 & .069 & 8.99537 \\
\hline
\end{tabular}

Pada tabel 2 diketahui nilai $\mathrm{r}^{2}$ atau $\mathrm{R}$ Square yaitu .072. Jadi dapat diketahui bahwa skor koefisien determinasi dalam penelitian ini adalah 7.2\%. Angka tersebut menjelaskan bahwa variabel ketergantungan pada media sosial hanya dipengaruhi sebesar $7.2 \%$ oleh variabel kecemasan sosial. Sedangkan sebanyak $92.8 \%$ lainnya dipengaruhi oleh variabel-variabel lain yang tidak diteliti dalam penelitian ini.

Berdasarkan tabel 2 dapat dilihat pula nilai SEE (Std. Eror of the Estimate) yaitu 8.95. Nilai tersebut lebih kecil daripada standar deviasi untuk variabel kriterion, yaitu 9.324 dalam tabel. Maka dari itu, karena nilai SEE < STD $(8.995<9.324)$, maka model regresi sudah baik dan dapat digunakan sebagai prediktor. Semakin kecil nilai SEE akan membuat model regresi semakin tepat untuk memrediksi variabel kriterion.

Perhitungan koefisien regresi. Bagian koefisien regresi menggambarkan persamaan regresi untuk mengetahui angka konstan dan uji hipotesis signifikansi koefisien regresi. Maka diketahui jika pvalue .000 sedangkan koefisien $\alpha$ yang ditentukan yaitu .05 yang artinya p-value $<\alpha(.000<.05)$ atau memenuhi syarat untuk menolak $\mathrm{H}_{0}$ dan menerima $\mathrm{H}_{1}$ yang berarti kecemasan sosial mempunyai pengaruh terhadap ketergantungan pada media sosial di kalangan mahasiswa UIN Sunan Gunung Djati Bandung.

Dalam penelitian ini juga diketahui bahwa persamaan regresi yang diperoleh yaitu $Y=46.387+.104 X$ yang artinya, setiap penambahan 1 pada variabel kecemasan sosial, maka ketergantungan pada media sosial akan meningkat sebesar .104. Sehingga dapat dikatakan bahwa semakin tinggi kecemasan sosial maka akan semakin tinggi pula ketergantungan media sosial pada mahasiswa.

Selain meneliti tentang hubungan kausalitas antara dua variabel, dalam penelitian ini juga dilakukan analisa terhadap gambaran variabel kecemasan sosial pada mahasiswa UIN Sunan Gunung Djati Bandung secara empiris. Berdasarkan hasil perhitungan maka diketahui bahwa rata-rata $($ mean $)=162.39$ dan median 162 dengan nilai minimum 88 serta nilai maksimum 247. Sedangkan rentang dalam penelitian ini adalah 159. Berdasarkan nilai rentang tersebut, maka peneliti mengategorikan kecemasan sosial menjadi tiga kategori yaitu: tinggi, sedang, dan rendah.

Mahasiswa yang memiliki tingkat kecemasan sosial tinggi adalah yang memiliki skor pada rentang 196-249. Skor yang berada pada rentang 142-195 termasuk kategori sedang. Adapun yang memiliki skor 88-141 memiliki tingkat kecemasan sosial yang rendah. 
Tabel 3

Sebaran Kategori Kecemasan Sosial

\begin{tabular}{lcc}
\hline \multicolumn{1}{c}{ Kategori } & Jumlah & Persentase \\
\hline Tinggi & 28 & $8.2 \%$ \\
Sedang & 255 & $74.6 \%$ \\
Rendah & 59 & $17.4 \%$ \\
Jumlah & 342 & $100 \%$ \\
\hline
\end{tabular}

Berdasarkan tabel 3, diketahui bahwa sebagian besar mahasiswa memiliki kecemasan sosial pada tingkat sedang yaitu dengan persentase $74.6 \%$ kemudian $8.2 \%$ kelompok subjek memiliki kecemasan sosial pada kategori tinggi. Sedangkan sisanya yaitu $17.2 \%$ kelompok subjek memiliki kecemasan sosial pada taraf yang rendah.

Berdasarkan hasil pengolahan data diketahui bahwa rata-rata ketergantungan media sosial pada kelompok subjek adalah 63.20 dengan nilai minimum 29 nilai maksimum 96 serta titik tengah 63 . Adapun rentang antara nilai minimum dan nilai maksimum adalah 67. Sehingga peneliti membagi tingkat ketergantungan media sosial pada kelompok subjek menjadi tiga kategori yaitu: tinggi, sedang, dan rendah.

Kelompok subjek yang memiliki skor pada rentang 75-97 termasuk pada kategori ketergantungan media sosial yang tinggi. Kelompok subjek yang memiliki skor pada rentang 52-74 termasuk pada dalam kategori ketergantungan pada media sosial yang sedang. Adapun kelompok subjek dengan ketergantungan media sosial pada kategori rendah adalah yang memiliki skor pada rentang 29-51.

Tabel 4

Sebaran Kategori Ketergantungan Media Sosial

\begin{tabular}{lcc}
\hline \multicolumn{1}{c}{ Kategori } & Jumlah & Persentase \\
\hline Tinggi & 34 & $10 \%$ \\
Sedang & 271 & $79.2 \%$ \\
Rendah & 37 & $10.8 \%$ \\
Jumlah & 342 & $100 \%$ \\
\hline
\end{tabular}

Berdasarkan tabel 4, diketahui bahwa sebagian besar mahasiswa memiliki ketergantungan media sosial pada tingkat sedang yaitu dengan persentase $79.2 \%$ kemudian $10 \%$ kelompok subjek memiliki ketergantungan media sosial pada kategori tinggi. Sedangkan sisanya yaitu $10.8 \%$ kelompok subjek memiliki ketergantungan media sosial pada taraf yang rendah. Hal tersebut membuktikan bahwa mahasiswa UIN Sunan Gunung Djati Bandung yang menjadi subjek penelitian memiliki ketergantungan pada media sosial, meskipun dalam taraf yang berbeda.

\section{Pembahasan}

Penelitian ini memiliki tujuan untuk mengetahui pengaruh kecemasan sosial terhadap ketergantungan media sosial pada mahasiswa. Hasil pengujian hipotesis menunjukkan bahwa kecemasan sosial mempunyai pengaruh terhadap ketergantungan pada media sosial. Dalam penelitian ini, diperoleh kecemasan sosial memiliki kontribusi terhadap ketergantungan media sosial pada mahasiswa. Sedangkan sebagian besar pengaruh disebabkan oleh variabel-variabel lain yang belum diteliti dalam penelitian ini. Hasil penelitian ini mengasumsikan bahwa kecemasan sosial tidak bisa berdiri sendiri untuk memengaruhi variabel dependen, artinya bisa jadi faktor-faktor lain di luar kecemasan sosial yang mungkin juga memberikan efek besar terhadap munculnya perilaku ketergantungan terhadap media sosial.

Penelitian ini juga menyatakan bahwa kecemasan sosial berpengaruh signifikan terhadap ketergantungan pada media sosial sebagai variabel kriterion. Hasil uji kelayakan menyatakan bahwa variabel kecemasan sosial layak digunakan untuk menentukan variabel ketergantungan pada media sosial, dengan begitu dapat dikatakan jika variasi pada kecemasan sosial turut meningkatkan variasi pada variabel ketergantungan pada media sosial. Hal ini bisa jadi terjadi karena ketergantungan terhadap media sosial sangat berkaitan dengan bagaimana individu itu melakukan mekanisme pertahanan diri terhadap respon lingkungannya sehingga perilaku kecemasan mereka tersebut salah satunya termanifestasikan ke dalam perilaku ketergantungan pada media sosial (Halim \& Sabri, 2013). 
Menurut Halim dan Sabri (2013) perilaku yang ditunjukan oleh individu ketika berinteraksi secara berlebihan dengan aktivitas di media sosial atau online, juga merupakan bentuk coping strategy yang mereka terapkan dalam merespon lingkungan mereka. sehingga suatu kewajaran jika hal tersebut terjadi di era globalisasi seperti ini (Gedam, Shivji, Goyal, Modi, \& Ghosh, 2016).

Mahasiswa yang memiliki tingkat kecemasan sosial tinggi atau orang yang memiliki gangguan kondisi sosial pada lingkungannya akan mendorong orang tersebut untuk menggunakan media sosialnya secara berlebihan dan terlibat dalam komunikasi online yang mendalam. Mereka akan merasa aman dengan cara masuk dan berinteraksi dalam dunia maya (McQuail, 2011). Hal tersebut menjadi satu-satunya cara untuk memeroleh hubungan, mengembangkan, dan membangun hubungan dengan orang lain. Mengingat bahwa manusia merupakan makhluk sosial maka tentunya akan selalu membutuhkan orang lain untuk berbagi cerita dengan mencurahkan isi hatinya dan meminta pertolongan. Hal tersebut sejalan dengan penelitian yang dilakukan oleh Fullwood, Quinn, Kaye, dan Redding, (2017) yang menunjukkan bahwa aktivitas relasional di media sosial adalah salah satu bentuk individu dalam mengembangkan model sosialnya terhadap lingkungan. Sehingga media sosial bagi mereka merupakan alat yang sangat efektif untuk memeroleh kebutuhan sosialnya karena tidak terpenuhi di dalam kehidupan nyata (Fullwood dkk., 2017). Pada akhirnya, orang-orang tersebut akan mengalami ketergantungan pada media sosial.

Bagi mahasiswa yang memiliki ketergantungan pada media sosialnya akan mengalami kesulitan dalam hal mengontrol penggunaan media sosial, hal tersebut akan berpengaruh pada gangguan psikologis (Littlejohn, 2009). Pada mahasiswa munculnya ketergantungan media sosial ini dapat diakibatkan oleh beberapa hal, seperti untuk bersosialisasi seara berlebih- an (mengirim pesan, chatting, dan mengirim e-mail) maupun untuk bermain game online secara berlebihan. Mahasiswa yang memiliki ketergantungan media sosial selain karena kurangnya kontrol dalam penggunaan media sosialnya, juga lamanya waktu yang digunakan akan berakibat pada berkurangnya interaksi secara langsung dengan orang lain (Panda \& Jain, 2018). Dengan demikian, penelitian lainnya yang dilakukan oleh Panda dan Jain (2018) menunjukkan adanya suatu kecenderungan yang berlebihan terhadap penggunaan media sosial akan mengakibatkan individu menjadi compulsive user sehingga jika hal ini tidak diantisipasi oleh mereka, bukan tidak mungkin akan mengganggu dinamika psikologis seseorang.

Lain halnya dengan mahasiswa yang tidak memiliki kecemasan sosial, mereka akan cenderung lebih aktif di dunia nyata dibandingkan dengan orang-orang yang memiliki rasa khawatir dan takut untuk bersosialisasi. Hal ini sejalan dengan yang dinyatakan oleh Bessière, Kiesler, Kraut, dan Boneva (2008) bahwa terdapat perbedaan dalam memanfaatkan internet dan dampak yang dihasilkan antara individu yang memiliki dukungan sosial dengan individu yang tidak memiliki dukungan sosial di lingkungannya. Mahasiswa yang aktif dalam media sosial di kehidupan nyata akan cenderung memanfaatkan media sosialnya untuk komunikasi online dalam memperkuat hubungan komunikasi dunia nyata tanpa harus tergantung pada media sosial, karena fungsinya hanya melengkapi saja.

Hal ini sejalan dengan penelitian yang dilakukan oleh Young (2011). Menurutnya kecemasan sosial memiliki korelasi yang positif dengan pathological internet use (PIU). Ini membuktikan secara teoretis bahwa kecemasan sosial merupakan sebagai prediktor atau sebab dari ketergantungan media sosial. Hal ini menginterpretasikan bahwa penelitian ini dapat memberikan kontribusi dalam pengembangan ilmu pengetahuan khusus- 
nya kajian tentang integrasi antara konsep kecemasan sosial dan ketergantungan media sosial. Penggabungan diantara kedua variabel tersebut telah menghasilkan hubungan yang positif dan signifikan.

Mayoritas subjek dalam penelitian ini berada pada hubungan positif dimana apabila tingkat kecemasan sosial mereka masuk dalam kategori tinggi, maka kelompok subjek juga memiliki tingkat ketergantungan pada media sosial yang tinggi begitupun yang lainnya. Sedangkan beberapa kelompok subjek yang antara kecemasan sosial dan ketergantungan media sosial berada pada taraf yang berbeda, hal itu dapat disebabkan oleh faktor-faktor lain yang tidak dibahas dalam penelitian ini. Hal lainnya yang juga menunjukkan bahwa kebanyakan mahasiswa berada pada kelompok tinggi di skor ketergantungan media sosial, dimungkinkan karena mereka berada pada fase dinamis yang kemudian banyak sekali permasalahan yang dihadapi dan merujuk pada psychological distress sehingga untuk bertahan dalam situasi tersebut salah satunya dilakukan dengan aktivitas di media sosial (Saquib dkk., 2017).

Bentuk pengaruh kecemasan sosial terhadap ketergantungan pada media sosial juga diketahui melalui persamaan regresi yang hasilnya memiliki makna bahwa setiap penambahan satu pada variabel kecemasan sosial, maka ketergantungan pada media sosial akan meningkat. Sehingga dapat dikatakan bahwa semakin tinggi kecemasan sosial maka akan semakin tinggi pula ketergantungan pada media sosial di kalangan mahasiswa UIN Sunan Gunung Djati Bandung. Persamaan regresi tersebut cukup untuk menjelaskan adanya hubungan kausalitas antara dua variabel yaitu variabel kecemasan sosial dan ketergantungan media sosial.

\section{Simpulan}

\section{Simpulan dan Saran}

Berdasarkan hasil yang diperoleh dari pengambilan data dan pembahasan diperoleh kesimpulan bahwa terdapat pe- ngaruh dari kecemasan sosial terhadap ketergantungan media sosial secara signifikan. Variabel ketergantungan media sosial hanya dipengaruhi sekitar $7.2 \%$ oleh variabel kecemasan sosial.

Variabel kecemasan sosial terbukti memengaruhi variabel ketergantungan pada media sosial di kalangan mahasiswa UIN Sunan Gunung Djati Bandung. Setiap penambahan 1 pada variabel kecemasan sosial, maka ketergantungan media sosial akan meningkat sebesar .104. Sehingga dapat dikatakan bahwa semakin tinggi kecemasan sosial maka akan semakin tinggi pula ketergantungan pada media sosial di kalangan mahasiswa tersebut. Adapun secara kategorik, mahasiswa UIN Sunan Gunung Djati Bandung mempunyai kecemasan sosial dan ketergantungan media sosial yang mayoritas termasuk ke dalam kategori sedang.

\section{Saran}

Beberapa saran yang dapat disampaikan yaitu: pertama, bagi instansi UIN Sunan Gunung Djati Bandung diperlukan adanya seminar atau diskusi ilmiah tentang perkembangan media sosial, agar mahasiswa dapat menggunakan media sosialnya secara bijak. Kedua, bagi penelitian selanjutnya diharapkan untuk mengembangkan kembali penelitian terhadap kecemasan sosial dan faktor-faktor atau variabel lain yang memengaruhi ketergantungan pada media sosial selain kecemasan sosial. Selain itu diharapkan dapat mengembangkan kembali alat ukur agar semakin dapat menggambarkan dengan akurat dimensidimensi kecemasan sosial maupun ketergantungan pada media sosial sesuai dengan budaya yang ada pada populasi.

\section{Daftar Pustaka}

APJII. (2015). Profil pengguna internet Indonesia, Asosiasi Penyelenggara Jasa Internet Indonesia.

Bessière, K., Kiesler, S., Kraut, R., \& Boneva, B. S. (2008). Effects of internet use and social resources on 
changes in depression. Information Communication and Society, 11(1), 47-70. doi.org/10.1080/13691180701858851

D Griffiths, M. (2013). Social Networking addiction: Emerging themes and issues. Journal of Addiction Research \& Therapy, 04(05), 4-5. oi.org/10.4172/2155-6105.1000e118

Fullwood, C., Quinn, S., Kaye, L. K., \& Redding, C. (2017). My virtual friend: A qualitative analysis of the attitudes and experiences of Smartphone users: Implications for Smartphone attachment. Computers in Human Behavior, 75, 347-355. doi.org/10.1016/j.chb.2017.05.029

Geçer, A. K., \& Gümüş, A. E. (2010). Prediction of public and private university students' communication apprehension with lecturers. Procedia - Social and Behavioral Sciences, 2(2), 3008-3014. doi.org/10.1016/j.sbspro.2010.03.456

Gedam, S. R., Shivji, I. A., Goyal, A., Modi, L., \& Ghosh, S. (2016). Comparison of internet addiction, pattern and psychopathology between medical and dental students. Asian Journal of Psychiatry, 22, 105-110. doi.org/10.1016/j.ajp.2016.06.007

Greca, A. M. La, \& Lopez, N. (1998). Social anxiety among adolescents: Linkages with peer relations and friendships. Journal of Abnormal Child Psychology, 26(2), 83-94.

Halim, M. H. A., \& Sabri, F. (2013). Relationship between defense mechanisms and coping styles among relapsing addicts. Procedia - Social and Behavioral Sciences, 84, 18291837.

doi.org/10.1016/j.sbspro.2013.07.043

Kandell, J. (1998). Internet addiction on campus: The vulnerability of college students. CyberPsychology \& Behavior, 1(1), 11-17. doi.org/10.1089/cpb.1998.1.11

Lemmens, J. S., Valkenburg, P. M., \& Peter, J. (2009). Development and validation of a game addiction scale for adolescents development and validation of a game. Media Psychology, 12(1), 77-95. doi.org/10.1080/15213260802669458

Panda, A., \& Jain, N. K. (2018). Compulsive smartphone usage and users' ill-being among young Indians: Does personality matter? Telematics and Informatics, 35(5), 1355-1372.

doi.org/10.1016/j.tele.2018.03.006

Saquib, N., Saquib, J., Wahid, A. W., Ahmed, A., Dhuhayr, H., Zaghloul, M., ... Al-Mazrou, A. (2017). Video game addiction and psychological distress among expatriate adolescents in Saudi Arabia. Addictive Behaviors Reports.

doi.org/10.1016/j.abrep.2017.09.003

Schrock, A. (2006). Myspace or ourspace: A media system dependency view of myspace. Doctoral Dissertation, University of Central Florida.

Smahel, D., Brown, B. B., \& Blinka, L. (2012). Associations between online friendship and internet addiction among adolescents and emerging adults. Developmental Psychology, 48(2), 381-388. doi.org/10.1037/a0027025

Soliha, S. F. (2015). Tingkat ketergantungan pengguna media sosial dan kecemasan sosial. Jurnal Ilmu Komunikasi, 4(1), 1-10. /doi.org/10.14710/INTERAKSI,4,1,1 $-10$

Sugiyono. (2014). Metode penelitian kuantitatif kualitatif dan $R \& D$. Bandung: Alfabeta.

Yahoo!-TNS Net Index Indonesia. (2016). Online media. Jakarta: Yahoo TNS.

Young, S., \& Kimberly. C. (2011). Internet addiction - A handbook and guide to evaluation and treatment. Canada: JohnWiley \& Sons Inc. 